\title{
Genetic differentiation in the queen breeding population of the western United States
}

\author{
NM Schiff, WS Sheppard * \\ USDA ARS, Bee Research Laboratory, BARC-East, Building 476, Beltsville, MD 20705, USA
}

(Received 19 June 1995; accepted 4 December 1995)

\begin{abstract}
Summary - Commercial honey bee queens in the United States are produced primarily in two geographically separated regions, one in the southeastern US and the other in central California. We used mitochondrial DNA and allozyme variation to characterize 178 breeder queen colonies from 22 California apiaries. Two colonies had the mtDNA haplotype characteristic of Apis mellifera mellifera, the first subspecies known to be introduced to the US, and 176 had the haplotype associated with $A \mathrm{~m}$ carnica and $A$ m ligustica, the most popular commercially available subspecies. Malate dehydrogenase $(M d h)$ allele frequencies for the western population, $M d h^{65}=0.65, M d h^{80}=0.09$ and $M d h^{100}=0.26$, were significantly different from those previously reported for feral and southeastern commercial populations. Among the California samples, bees described by apiarists as 'Italian' or 'Carniolan' were significantly different from each other based on $M d h$ allele frequencies. Five other enzymes known to be polymorphic in honey bees were invariant in the California samples. Differentiation between populations in the United States suggests they may act as reservoirs for genes that can be useful for bee breeding programs.
\end{abstract}

\section{Apis mellifera / allozyme / population genetics / mitochondrial DNA}

\section{INTRODUCTION}

Since the introduction of the African honey bee subspecies Apis mellifera scutellata to Brazil and the spread of its descendants, Africanized bees, through the Americas, there has been increased interest in identifying the subspecific heritage of introduced honey bees. Several attempts to develop reliable methods for identification of African- ized bees have used allozymes, particularly malate dehydrogenase, to characterize Africanized and US populations (Sylvester, 1976; Nunamaker, 1980; Page and Metcalf, 1988; Spivak et al, 1988; Hung et al, 1991). These studies demonstrated differences in malate dehydrogenase (Mdh) allele frequencies between US and Africanized samples, but also varied in their allele frequency estimates for US samples.

* Correspondence and reprints: Department of Entomology, Washington State University, Pullman, WA 99164, USA 
There are several hypotheses that could explain the frequency differences observed among US samples. One possibility is that allele frequencies have changed over time. The above studies occurred over a 15-year period and it is possible that allele frequencies changed from the earliest study to the most recent. Page and Metcalf (1988) addressed this issue by estimating allele frequencies of a Davis, California population for 1977 and 1978 and comparing their results to frequencies calculated earlier for the same population by Sylvester (1976). They concluded that allele frequencies, at least for the Davis locale, were relatively stable and did not change over the period sampled.

A second hypothesis is that sample size or confounding sampling errors could potentially produce anomalous results (Page, 1989). For instance, if the number of colonies sampled is low, there is the potential to bias the allele frequency estimates if one or more of the sampled colonies is aberrant. This can be compounded by sampling multiple individuals per colony, effectively overrepresenting the queen's, and potentially an individual drone's, genotype. In the studies listed above the number of colonies ranged from 8 to 74 (average $=26.8$ ) and multiple individuals per colony were sampled.

A third hypothesis is that the samples were collected from different gene pools created by selection or genetic drift. Replacement queens for commercial colonies in the United States are produced by queen-breeding apiaries that are not evenly distributed across the United States. In fact, their distribution is disjunct, with approximately half the apiaries in the southeastern United States (Schiff and Sheppard, 1995) and the other half clustered in central California. Because of the large distance between the two regions, it is likely that these areas are reproductively isolated and that the populations have experienced dif- ferent selective regimes, were founded from different introductions, or diverged as a result of genetic drift.

There is some precedent, based on morphological characters, for the ability of beekeepers to select and maintain differences in honey bee populations. Alpatov (1929) reported that US beekeepers had selected strains of $A m$ ligustica that were larger and more yellow than the original $A m$ ligustica from Italy. Similarly, within introduced populations of $A$ m carnica, German beekeepers have selected several characters, including cubital index, to match the values of pure A $m$ carnica, while non-selected characters deviate from the original values (Moritz, 1991; Kauhausen-Keller and Keller, 1994).

The separate gene pool hypothesis is further supported when the origin of the samples analyzed in previous studies is taken into account. The three studies with allele frequency estimates that differed from a southeastern population sampled by Schiff and Sheppard (1995) were those of Sylvester (1976), Nunamaker (1980) and Page and Metcalf (1988). In these studies Sylvester and Page and Metcalf sampled colonies only from the western (Californian) queen-breeding region and Nunamaker sampled from both eastern and western regions. The other studies with allele frequency estimates that did not differ from Schiff and Sheppard (1995) were mostly eastern. Thus, it seems likely that eastern and western queen breeders have selected or maintained some genetic differences, in the eastern and western United States respectively.

Some honey bee subspecies can be differentiated on the basis of mitochondrial DNA RFLP variation. Six-base recognizing restriction enzymes, such as $E c o R 1$, are used to differentiate African from European subspecies and, within the European subspecies, between eastern Mediterranean ( $A$ m carnica, $A$ m ligustica) and western 
European ( $A m$ mellifera, A $m$ iberica) subspecies groups (see the review by Smith, 1991). Recent analyses with a four-base recognizing restriction enzyme, Hinf 1 , allow further discrimination, especially of some African subspecies (Smith et al, 1991; Sheppard et al, 1995).

Mitochondrial DNA and allozyme analyses of southern feral and southeastern breeder queen US populations have revealed significant differences in the maternal origins of these populations (Schiff and Sheppard, 1993, 1995; Schiff et al, 1994). The purpose of this study was to genetically characterize the western breeder queen population by analyzing colonies from California apiaries. This population was compared with the southern feral and southeastern breeder queen populations.

\section{MATERIALS AND METHODS}

Most western queen-producing apiaries are located in a region of central California within a $250 \mathrm{~km}$ radius of Davis, California (Schiff and Sheppard, 1995). We sampled 21 commercial queen-producing apiaries from that region, identified from recent advertizing literature. Workers were collected from colonies representing 178 breeder queens. In most cases breeder queen colonies were sampled, but in a few cases breeder queen colonies were unavailable and colonies headed by daughters of breeder queens were sampled. If it was impossible to distinguish different breeder queen lines within an apiary then only one sample was chosen to represent that apiary. In one apiary, breeder queen colonies prepared for the next year (1995) were sampled. Samples were frozen and stored in liquid nitrogen until they could be held at $-80^{\circ} \mathrm{C}$ at the Beltsville Laboratory. Each apiarist was interviewed and the number of breeder queens used that year and the number of queens produced was recorded. For the breeder queen colonies prepared for 1995, queen production was expected to be the same as 1994, so the number of queens produced in 1994 was used as an estimate of anticipated queen production.
Two kinds of bees were offered for sale by the western queen breeders: Carniolans (including 'Yugo', Rinderer et al, 1993) and Italians, which were both commercial strains of subspecies originally introduced to the US in the 19th century (Sheppard, 1989). In our sample of 178 breeder queen colonies, $119(67 \%)$ were described as Italian and $59(33 \%)$ were Carniolan. Nucleic acid extraction and mitochondrial DNA analysis using the six-base recognizing restriction enzyme EcoR1, were conducted as previously described (Sheppard and McPheron, 1991; Sheppard et al, 1991), except that three worker thoraces per colony were extracted. This ensured a high yield of mitochondrial DNA and eliminated the need to transfer DNA to nylon filters and use radioactive mtDNA probes. Following restriction enzyme digestion, agarose gel electrophoresis and treatment with ethidium bromide, the mtDNA fragments could be visualized and photographed directly under UV light.

Allozyme analysis was performed on a single worker bee thorax for each of the 178 colonies. We analyzed a single worker per colony to prevent overrepresentation of the queen's or a particular drone's genotype. Samples were electrophoresed on $12 \%$ starch gel (Starch Art Corp, Austin, TX) using methods described previously (Sheppard and Berlocher, 1984, 1985; Del Lama et al, 1988). Six enzyme systems known to be polymorphic in adult honey bees were examined. They were: malate dehydrogenase $(M d h-1)$, malic enzyme $(M e)$, hexokinase $(H k)$, aconitase (Acon1), phosphoglucomutase $(\mathrm{Pgm})$, and esterase (Est-3) (Mestriner and Contel, 1972; Sheppard and Berlocher, 1984, 1985; Sheppard and McPheron, 1986; Del Lama et al, 1988). Mendelian inheritance of electromorphs was assumed, although this has not been established for Me, Pgm or Acon-1.

Significant differences in allele frequencies were determined by Fisher exact test analysis of $2 \times 3$ contingency tables. Fisher exact tests were computed on counts of alleles using the statistical analysis program SAS ${ }^{\circledR}(1988)$. Direct comparisons of allele frequencies between this study and previous studies of the eastern commercial and feral populations (Schiff et al, 1994; Schiff and Sheppard, 1995) were possible because single workers per colony were analyzed in each case. Allele frequency comparisons with earlier studies, which sampled multiple workers per colony, were made by estimating counts of alleles as if a single worker per colony were sampled (multiplying reported allele frequencies by twice 
the number of colonies sampled per study). Deviations from Hardy-Weinberg equilibrium were determined by $\chi^{2}$ analysis using the Biosys- 1 program (Swofford and Selander, 1981).

\section{RESULTS AND DISCUSSION}

The 21 western apiaries sampled used a total of 295 breeder queens to produce 406800 queens. Each breeder queen, therefore, produced an average of 1379 daughter queens, similar to the average of 1571 produced by 308 breeder queens from 22 queen producing apiaries in the southeastern United States (Schiff and Sheppard, 1995). There are approximately 3.2 million actively-maintained commercial colonies in the US (USDA Agricultural Statistics Board, 1993); therefore the western apiaries produced replacement queens for nearly $13 \%$ of commercial colonies in the US. Our sample of 178 colonies represented $61 \%$ of the breeder queens from the 21 apiaries and, thus, approximately 248000 commercial colonies. The relative number of queens produced by each strain were approximately 171120 Italian and 76880 Carniolan queens.
Two mitochondrial DNA haplotypes were identified in the western commercial breeder queen sample. Two colonies (1.1\%), from different apiaries, had the haplotype associated with $A m$ mellifera or $A m$ iberica (Smith et al, 1991) and the remaining 176 $(98.9 \%)$ had the haplotype associated with $A m$ ligustica and $A$ m carnica (table I). Despite their $A$ m mellifera mtDNA haplotypes, the former colonies were designated as Italian ( $A m$ ligustica) by the apiarists. Presumably these represent maternal descendants of $A m$ mellifera queens that, over many generations, mated with Italian drones to the extent that the predominant phenotype (and nuclear genotype) is now Italian.

The low percentage of $A m$ mellifera haplotypes in the western sample is similar to the $3 \%$ found in the eastern commercial population (Schiff and Sheppard, 1995), but significantly $\left(P=8.74 \times 10^{-28}\right)$ lower than the $36 \%$ A m mellifera haplotypes reported in the feral population (Schiff et al, 1994). None of the colonies had the $A$ m lamarckii haplotype found in low frequency in the feral population (Schiff and Sheppard, 1993; Schiff et al, 1994), supporting the hypothesis that feral colonies with the $A$ m lamarckii haplotype are maternal descendants of

Table I. Mdh allele frequencies and mitochondrial DNA haplotypes for the western breeder queen population.

\begin{tabular}{|c|c|c|c|c|c|c|}
\hline \multirow{3}{*}{ Designation } & \multirow{3}{*}{$\mathrm{N}$} & -... & $\ldots$ & ... & \multicolumn{2}{|c|}{$\ldots \ldots$} \\
\hline & & & Alleles & & \multicolumn{2}{|c|}{ Haplotypes } \\
\hline & & $M d h^{65}$ & $M d h^{80}$ & Mdh 100 & mel/ibr & car/lig \\
\hline- - & & & & & & \\
\hline Italian & 119 & 0.71 & 0.10 & 0.19 & 2 & 117 \\
\hline Carniolan & 59 & 0.51 & 0.07 & 0.42 & - & 59 \\
\hline Total & 178 & 0.65 & 0.09 & 0.26 & 2 & 176 \\
\hline Weighted frequencies ${ }^{a}$ & - & 0.70 & 0.08 & 0.22 & - & - \\
\hline
\end{tabular}

a Allele frequencies for the total population weighted by the proportion of marketable queens produced by each apiary. Weighted frequencies were not significantly different from total frequencies (Fisher exact test, $P=0.302$ ). 
historical introductions from the 19th century that have survived in the feral population and not recent swarms from commercial stock.

Analysis of the six allozymes known to be polymorphic in Apis mellifera revealed that, as with the southeastern breeder queen samples, only Mdh was polymorphic in the western breeder queen samples, and only the three most common Mdh alleles were detected (Schiff and Sheppard 1995). Within the six allozymes, one polymorphism and a total of eight alleles were detected in the US breeder queen population. In contrast, three of these six allozymes were polymorphic in the feral population with a total of eleven alleles (Schiff et al, 1994). A European population sample (Sheppard, 1988) was even more variable, with a total of four polymorphic allozymes and fifteen alleles detected. These results are consistent with the hypothesis that US commercial populations are the result of successive genetic bottlenecks. The first bottleneck was the initial introduction of honey bees to the United States. Of the 25 geographic subspecies recognized from the Old World (Ruttner, 1992), only eight were introduced to the US (Sheppard, 1989). The eight subspecies introduced, each representing only a small portion of the total variability in each subspecies, formed the basis of the feral US population. The commercial breeder queen populations have undergone a further bottleneck because they are selected strains of predominantly three subspecies, A $\mathrm{m}$ carnica, $A m$ caucasica and $A m$ ligustica.

Despite the overall reduction in genetic variability in US honey bee populations there is still potential for genetic differentiation. In fact, Mdh allele frequencies for the western commercial breeder queen population (table I) are significantly different than those of the southern feral US population $(P=4.09 \mathrm{x}$ $\left.10^{-21}\right)$ and the southeastern commercial breeder-queen population $\left(P=3.92 \times 10^{-6}\right)$, suggesting interrupted gene flow between the three groups. These differences, which also remain when the breeder queen allele frequencies are weighted by the proportion of queens they contribute to the total number of marketable queens produced, may be explained by unequal exchange of genetic material due to beekeeping practices. Genetic contributions from the commercial to the feral population occur via swarming of colonies and through dronemating flights. However, the input from feral honey bees to the commercial population is limited to drone mating, which beekeepers discourage by mating queens in areas heavily stocked with commercial drones, and in some cases by the use of artificial insemination. Presumably gene flow between the two queen breeding populations is reduced because of geographic isolation. This is supported by discussion with queen breeders who indicated that exchange of breeding stock between eastern and western regions was low.

Analysis by 'subspecific' strain designation was not significant in southeastern breeder queen samples (Schiff and Sheppard, 1995), but in the western breeder queen samples there were significant allele frequency differences (table I) between bees described as Italian and Carniolan $(P=1.49$ $\left.\times 10^{-5}\right)$. Although both Italian and Carniolan queen breeding operations are located in central California, the mating range of honey bees is normally less than $15 \mathrm{~km}$ (Peer and Farrar, 1956; Peer, 1957; Ruttner and Ruttner, 1972) and, thus, breeding yards may be isolated enough to produce the observed differentiation. Carniolan breeder queens were further segregated by the use of artificial insemination by some apiarists. However, neither population deviated significantly from Hardy-Weinberg expectations $(P=0.546,3 \mathrm{df}$ and $0.411,3 \mathrm{df}$ respectively), suggesting that inbreeding was not excessive.

Differences between southeastern and western commercial populations cannot be 
attributed solely to the presence of a separate Carniolan population in the west, because allele frequencies for the eastern breeder queen population were significantly different than those of both Italian and Carniolan strains in the western region $(P$ $=2.28 \times 10^{-6}$ and $6.62 \times 10^{-5}$ respectively) (table II). However, some differences in allele frequencies for US commercial populations reported in earlier studies may be explained by these results. The samples from Sylvester (1976) and Page and Metcalf (1988), for example, are both significantly different from the western Carniolan sample but not significantly different from the Italian sample (table II). It is interesting to note that Mdh allele frequencies reported for European A m carnica and A $m$ ligustica are quite variable, and therefore it is unclear whether the frequency differences we found in the western US. Italian and Carniolan populations reflect similar variation in the original subspecies (Nunamaker, 1980; Badino et al, 1984; Comparini and Biasiolo, 1991; Sheppard and McPheron, 1986).
The largest overall difference between western and southeastern breeder queen populations and southern feral populations is that the frequency of the $M d h^{80}$ allele is significantly lower in the western breeder queen population. We suggest this is the result of the history of the introduction of the different subspecies of honey bees to the US. European samples of $A m$ mellifera are characterized by high frequencies of the Mdh ${ }^{80}$ allele (Badino et al, 1983, 1984; Sheppard and Berlocher, 1984; Cornuet et al, 1986) while European $A$ m ligustica populations are characterized by low $M d h^{80}$ frequencies (Badino et al, 1984; Sheppard and Berlocher, 1985; Comparini and Biasiolo, 1991). By the 17th century $A m$ mellifera was established in the eastern US and over the next 200 years it expanded its range westward as feral and managed colonies (Oertel, 1976). Thus, when Italian bees were introduced to the eastern US in 1859 , there were large managed and feral populations of $A m$ mellifera that could contribute $M d h^{80}$ alleles into the commercial 'Italian' stocks via their drones. It is likely

Table II. $P$ values for comparisons a of $M d h$ allele frequencies between western breeder queen populations and commercial and feral populations from previous studies. $P$ values less than 0.05 indicate significant differences between populations.

Previous studies

Western breeder queen populations
Italian Carniolan

Commercial A

Commercial B

Commercial C

Commercial D

Commercial E

Commercial $\mathrm{F}$

Commercial G

Feral A

Feral B

$\begin{array}{ll}0.191 & 0.770 \\ 0.045 & 0.160 \\ 1.53 \times 10^{-11} & 5.63 \times 10^{-9} \\ 0.595 & 0.049 \\ 0.815 & 4.3 \times 10^{-3} \\ 2.28 \times 10^{-6} & 3.57 \times 10^{-12} \\ 0.188 & 0.332 \\ 5.05 \times 10^{-5} & 2.42 \times 10^{-5} \\ 1.63 \times 10^{-15} & 3.57 \times 10^{-12}\end{array}$

a Fisher exact test of $2 \times 3$ contingency tables

1. Spivak et al, 1988; 2. Hung et al, 1991; 3. Nunamaker, 1980; 4. Sylvester, 1976; 5. Page and Metcalf, 1988; 6. Schiff, and Sheppard, 1995; 7. Sheppard, 1988; 8. Schiff et al, 1994.

$\begin{array}{ll}0.516 & 1 \\ 0.099 & 2 \\ 8.07 \times 10^{-13} & 3 \\ 0.735 & 4 \\ 0.25 & 5 \\ 3.92 \times 10^{-6} & 6 \\ 0.866 & 7 \\ 2.1 \times 10^{-5} & 7 \\ 4.09 \times 10^{-21} & 8\end{array}$

Total Reference 
that feral $A m$ mellifera bees were not widespread in California, because colonies of $A m$ mellifera that were imported by ship sold for $\$ 100$ in 1858 (Watkins, 1967). This is an exceptionally high price, even by today's standards, and indicates that bees were rare in California at that time. Thus, when A m ligustica was introduced to California in the 1860's (Watkins, 1968) there were relatively few feral or managed colonies of $A m$ mellifera to provide a source of $M d h^{80}$ alleles.

Our results show that not only is there restricted gene flow among the western breeder queen, southeastern breeder queen and southern feral honey bee populations, but that within the western breeder queen population there are allele frequency differences between bees described as Italian or Carniolan. Since there is restricted gene flow between the populations, they may serve as reservoirs for different genes that could be useful for bee-breeding programs. To maximize the initial genetic variability of honey bee stocks for a breeding program in the United States, a breeder should certainly sample from the different populations described here. In a similar manner, breeding programs in general could take advantage of the diversity represented not only by different subspecies, but also by withinsubspecies variants, such as 'ecotypes' (Louveaux, 1969; Ruttner, 1975). Estimation of allele frequencies of commercial populations, measured by sampling breederqueen colonies, appears to be an easily replicable method. The results of repeated surveys could be used to measure the longterm effects of breeding efforts, Africanization or other population level phenomena on commercial populations.

\section{ACKNOWLEDGMENTS}

We would like to thank the following individuals for helping us to collect honey bee samples: $E$ Allen, R Brandi, T Covington, K Friesan, R Gannon, W
Harrison, $\mathrm{P}$ Heitkam, O Hill, N Hill, CF Koehnen, K Koehnen, L Little, D Lohman, J Moore, L Pankratz, H Park, S Park, T Parisian, F Pendell, K Powell, F Selby, R Shubert, K Smith, V Strachan, $\mathrm{K}$ Ward and $\mathrm{R}$ Zenisek. We also thank $\mathrm{DE}$ McCauley and BA McPheron for reviewing an earlier draft of this manuscript. This work was supported in part by NRICGP Grant no 9301929.

\section{Résumé - Différenciation génétique au sein de la population éleveuse de reines} de l'ouest des États-Unis. Diverses tentatives pour caractériser génétiquement les populations commerciales d'abeilles (Apis mellifera $L$ ) aux États-Unis ont fourni des estimations différentes des fréquences de l'allèle malate déshydrogénase (Sylvester, 1976 ; Nunamaker, 1980 ; Page et Metcalf, 1988 ; Spivak et al, 1988 ; Hung et al, 1991). Puisque les reines de remérage pour les colonies commerciales sont produites dans des régions éloignées (sud-est et ouest) des États-Unis, nous avons étudié l'éventualité selon laquelle ces populations seraient génétiquement isolées. Nous avons utilisé l'ADN mitochondrial et la variation allozymique pour caractériser 178 colonies éleveuses de reines réparties dans 22 ruchers en Californie. Les résultats ont été comparés avec ceux précédemment obtenus à partir de la population éleveuse de reines du sud-est et de la population sauvage du sud (Schiff et al, 1994 ; Schiff et Sheppard, 1995). Pour analyser l'ADNmt on a utilisé EcoR1, l'enzyme de digestion qui reconnaît six bases, comme décrit précédemment (Sheppard and McPheron, 1991, Sheppard et al, 1991), sauf que trois thorax d'ouvrières, et non pas deux, ont été extraits. L'analyse des allozymes pour six systèmes enzymatiques (Mdh-1, Hex, Acon, Est-3, Pgm et $M e$ ) a été réalisée sur un seul thorax d'ouvrière pour chacune des 178 colonies selon les méthodes décrites par Sheppard et Berlocher $(1984,1985)$ et Del Lama et al (1988). Deux colonies possédaient un haplotype d'ADNmt associé à $A m$ mellifera, la première race introduite aux 
États-Unis ; les 176 autres avaient un haplotype associé à $A m$ carnica et $A m$ ligustica, les deux races les plus en vogue chez les apiculteurs professionnels. La faible fréquence des haplotypes $A m$ mellifera est semblable à celle trouvée dans la population éleveuse de reines du sud-est mais significativement différente de celle de la population sauvage du sud-est (Schiff et al, 1994). Les fréquences de l'allèle $M d h$ pour la population éleveuse de reines de l'ouest $\left(M d h^{65}=0,65, M d h^{80}=0,09\right.$ et $M d h^{100}=$ 0,26 ) sont significativement différentes de celles des deux autres populations: éleveuses de reines du sud-est et sauvage du sud (tableau II). La population éleveuse de reines de l'ouest avait moins d'allèles $M d h^{80}$ (tableau I), vraisemblablement à cause de l'absence d'A $m$ mellifera en Californie quand a été introduite $A$ m ligustica. Au sein de la population éleveuse de reines de l'ouest, nous avons également trouvé des différences de fréquence de l'allèle $M d h$ entre les abeilles décrites comme italiennes et celles décrites comme carnioliennes (tableau I). II est intéressant de noter que les fréquences de l'allèle $M d h$ mentionnées chez les abeilles carnica et ligustica d'Europe sont très variables. On ne peut donc pas savoir si les différences de fréquence trouvées dans les populations italiennes et carnioliennes de l'ouest des ÉtatsUnis sont le reflet d'une variation similaire chez les races d'origine (Nunamaker, 1980 ; Badino et al, 1984 ; Comparini et Biasiolo, 1991 ; Sheppard et McPheron, 1986). Les cinq autres enzymes connus pour leur polymorphisme chez l'abeille domestique sont invariants dans les échantillons de Californie. Nos résultats montrent que la population d'abeilles des États-Unis se compose de sous-populations génétiquement isolées, susceptibles de jouer le rôle de réservoirs de gènes utiles pour les programmes de sélection de l'abeille. Ces programmes devraient profiter de la diversité représentée non seulement par les diverses races mais aussi par les variants sub-spécifiques tels que les écotypes (Louveaux, 1969 ; Ruttner, 1975).

\section{Apis mellifera / génétique population / allozyme / DNA mitochondrial / États- Unis}

\section{Zusammenfassung - Genetische Diffe- renzierung in der Königinnenzuchtpo- pulation der westlichen Vereinigten Staa-} ten von Amerika. Die bisherigen Versuche einer genetischen Charakterisierung der kommerziellen Honigbienenpopulation in den USA hatten zu unterschiedlichen Schätzungen der Allelfrequenzen für Malat-Dehydrogenase geführt (Sylvester, 1976 ; Nunamaker, 1980 ; Page und Metcalf, 1988 ; Spivak et al, 1988 ; Hung et al, 1991). Da die Ersatzköniginnen für kommerzielle Bienenvölker in voneinander getrennten südöstlichen und westlichen Regionen der Verejnigten Staaten produziert werden, untersuchten wir, ob diese Populationen möglicherweise genetisch isoliert sind. Zur Charakterisierung von 178 Völkern mit Königinnen von westlichen Züchtern aus 22 kalifornischen Bienenständen untersuchten wir die Variation der mitochondriellen DNA und der Allozyme. Die Ergebnisse wurden mit bereits zuvor beschriebenen Befunden aus der südöstlichen Zuchtköniginnenpopulation und mit der südlichen Population wildlebender Honigbienen verglichen (Schiff et al, 1994 ; Schiff und Sheppard, 1995). Zur Analyse der mitochondriellen DNA wurde das Restriktionsenzym EcoR1 mit sechsbasiger Erkennungssequenz verwendet (Sheppard and McPheron, 1991 ; Sheppard et al, 1991), allerdings wurde der Thorax von drei anstelle von zwei Arbeiterinnen extrahiert. Zur Untersuchung von sechs Allozymsystemen (Mdh-1, Hex, Acon, Est-3, $P g m$ und $M e$ ) wurden von jedem der 178 Völker jeweils ein Arbeiterinnenthorax nach den von Sheppard und Berlocher (1984, 1985) und Del Lama et al (1988) beschriebenen Methoden analysiert. Bei zwei der 
Völker war der mtDNA-Haplotyp mit $A m$ mellifera assoziiert, der ersten in die USA eingeführten Subspecies. Der Haplotyp der übrigen 176 Völker war mit $A m$ carnica und A $m$ ligustica assoziiert, dieses sind die kommerziell verbreitetsten Subspecies. Die geringe Häufigkeit des A m mellifera - Haplotyps ähnelt den Verhältnissen in der südöstlichen Zuchtköniginnenpopulation, unterscheidet sich dagegen signifikant von der südöstlichen Population wildlebender Honigbienen (Schiff et al, 1994). Die Allelfrequenzen der Malatdehydrogenase in der westlichen Zuchtköniginnenpopulation $\left(M d h^{65}=0,65, M d h^{80}=0,09\right.$ und $M d h^{100}=$ $0,26)$ unterscheiden sich sowohl von der südöstlichen Zuchtköniginnenpopulation als auch von der südlichen Population wildlebender Bienen (Tabelle II). Die westliche Zuchtköniginnenpopulation hatte einen geringeren Anteil an $M d h^{80}$ (Tabelle I). Der Grund ist wahrscheinlich, daß es in Kalifornien zur Zeit der Einführung von $A$ m ligustica keinen Bestand an $A m$ mellifera gab. Auch innerhalb der westlichen Zuchtköniginnenpopulation gibt es signifikante Unterschiede der Mdh Allelfrequenzen zwischen als "italienisch" oder "carniolisch" beschriebenen Bienen (Tabelle I). Interessanterweise sind die bei europäischen $A m$ carnica und $A$ m ligustica gefundenen Mdh-Allelfrequenzen sehr variabel. Es ist daher unklar, ob die von uns in den westlichen italienischen und carniolischen Populationen gefundenen Unterschiede der Allelfrequenzen Unterschiede der originalen Subspecies reflektieren (Nunamaker, 1980; Badino et al, 1984; Comparini und Biasolo, 1991; Sheppard and McPheron, 1986). Die fünf weiteren, bei Honigbienen bekanntermaßen polymorphen Enzyme unterschieden sich in den kalifornischen Proben nicht. Unsere Ergebnisse weisen darauf hin, daß die Honigbienenpopulation in den USA aus genetisch getrennten Subpopulationen besteht, die als genetisches Reservoir in Bienenzuchtprogrammen genutzt werden können. Wir schlagen vor, daß Zuchtpro- gramme nicht nur die Diversität der unterschiedlichen Subspecies nutzen sollten, sondern ebenso die z B durch Ökotypen repräsentierte Variation innerhalb der Subspecies (Louveaux 1969, Ruttner 1975).

\section{Apis mellifera / Allozyme / Populations- genetik / mitochondrielle DNA}

\section{REFERENCES}

Alpatov WW (1929) Biometrical studies on variation and races of the honey bee (Apis mellifera $\mathrm{L}$ ). Quart Rev Bio/ 4, 1-58

Badino G, Celebrano G, Manino A (1983) Population structure and Mdh-1 locus variation in Apis mellitera ligustica. $J$ Hered 74, 443-446

Badino G, Celebrano G. Manino A (1984) Population genetics of Italian honeybee (Apis mellifera ligustica Spin) and its relationships with neighbouring subspecies. Boll Mus Reg Sci Nat Torino 2, 571584

Comparini A, Biasiolo A (1991) Genetic discrimination of Italian bee, Apis mellifera ligustica versus Carniolan bee, Apis mellifera carnica by allozyme variability analysis. Biochem System Ecol 19, 189-194

Cornuet JM, Daoudi A, Chevalet C (1986) Genetic pollution and number of matings in a black honey bee (Apis mellifera mellifera) population. Theor Appl Genet 73, 223-227

Del Lama MA, Figueiredo RA, Soares AEE, Del Lama SN (1988) Hexokinase polymorphism in Apis mellifera and its use for Africanized honeybee identification. Rev Braz Genet 11, 287-297

Hung ACF, Rubink WL, Crewe RM (1991) Association of enzyme/protein loci in individual honey bees (Apis mellifera L) (Hymenoptera: Apidae). Bee Sci 1, 225229

Kauhausen-Keller D, Keller R (1994) Morphometrical control of pure race breeding in the honey bee (Apis mellifera L) Apidologie 25, 133-143

Louveaux J (1969) Ecotype in honey bees. Proceedings XXII International Beekeeping Congress, Munich. Apimondia, Bucharest, Romania 22, 499501

Mestriner MA, Contel EPB (1972) The P-3 and Est loci in the honey bee Apis mellifera. Genetics 72, 733-738

Moritz RFA (1991) The limitations of biometric control on pure race breeding in Apis mellifera. $J$ Apic Res $30,54-59$

Nunamaker RA (1980) Subspecies determination in the honey bee (Apis mellifera $L$ ) based on isoelectric 
focusing of malate dehydrogenase. Ph D thesis. University of Wyoming, Laramie, WY

Oertel E (1976) Bicentennial bees. Am Bee J116, 70-71, $114,128,156-157,214-215,260-261,290$

Page RE Jr (1989) Neotropical African bees. Nature $339,181-182$

Page RE, Metcalf RA (1988) A population estimate of $\mathrm{MDH}$ allozyme frequencies for the honey bee, Apis mellifera L (Hymenoptera: Apidae). Pan Pac Entomol $64,285-289$

Peer DF (1957) Further studies on the mating range of the honey bee, Apis mellifera L. Can Entomol 89, $108-110$

Peer DF, Farrar CL (1956) The mating range of the honey bee. J Econ Entomol 49, 254-256

Rinderer TE, de Guzman LI, Kulincevic JM, Delatte GT, Beaman LD, Buco SM (1993) The breeding, importing, testing and general characteristics of Yugoslavian honey bees bred for resistance to Varroa jacobsoni. Am Bee J 133, 197-200

Ruttner H, Ruttner F (1972) Untersuchungen über die Flugaktivität und das Paarungsverhalten der Drohnen. 5. Drohnensammelplätze und Paarungdistanz. Apidologie 3, 203-232

Ruttner F (1975) Races of bees. In: The Hive and the Honey Bee (Dadant \& Sons, eds), Dadant \& Sons, Hamilton, 19-38

Ruttner $F(1992)$ Naturgeschichte der Honigbienen. Ehrenwirth, Munich

SAS (1988) SAS/STATTM User's Guide, Release 6.03 Edition. SAS Institute Inc, Cary, NC

Schiff NM, Sheppard WS (1993) Mitochondrial DNA evidence for the 19th century introduction of African honey bees into the United States. Experientia 49, 350-352

Schiff NM, Sheppard WS (1995) Genetic analysis of commercial honey bees (Hymenoptera: Apidae) from the southern United States. J Econ Entomol 88, 1216-1220.

Schiff NM, Sheppard WS, Loper G M, Shimanuki H (1994) Genetic diversity of feral honey bee (Hymenoptera: Apidae) populations in the southern United States. Ann Entomol Soc Am 87, 842-848

Sheppard WS (1988) Comparative study of enzyme polymorphism in United States and European honey bee (Hymenoptera: Apidae) populations. Ann Entomol Soc Am 81, 886-889

Sheppard WS (1989) A history of the introduction of honey bee races into the United States. Am Bee $J$ $129,617-619$ and $664-667$
Sheppard WS, Berlocher SH (1984) Enzyme polymorphisms in Apis mellifera mellifera from Norway. $J$ Apic Res 23, 64-69

Sheppard WS, Berlocher SH (1985) New allozyme variability in Italian honey bees, Apis mellifera ligustica. $J$ Hered 76, 45-48

Sheppard WS, McPheron BA (1986) Genetic variation in honey bees from an area of racial hybridization in western Czechoslovakia. Apidologie 17, 21-32

Sheppard WS, McPheron BA (1991) Ribosomal DNA diversity in Apidae. In: Diversity in the genus Apis (DR Smith, ed), Westview Press, Boulder, CO, 89102

Sheppard WS, Rinderer TE, Mazzoli JA, Stelzer JA, Shimanuki H (1991) Gene flow between Atricanand European-derived honey bee populations in Argentina. Nature 349, 782-784

Sheppard WS, Rinderer TE, Meixner MD, Yoo HR, Stelzer JA, Schiff NM, Kamel SM, Krell R (1995) Hinf 1 variation in mitochondrial DNA of Old World honey bee races. $J$ Hered (In press)

Smith DR (1991) African bees in the Americas: insights from biogeography and genetics. Trends Ecol Evol $6,17-21$

Smith DR, Palopoli MF, Taylor OR, Garnery L, Cornuet JM, Solignac M, Brown WM (1991) Geographical overlap of two mitochondrial genomes in Spanish honey bees (Apis mellifera iberica). J Hered 82, 96100

Spivak M, Ranker T, Taylor O Jr., Taylor W, Davis L (1988) Discrimination of Africanized honey bees using behavior, cell size, morphometrics, and a newly discovered isozyme polymorphism. In: Africanized Honey Bees and Bee Mites (GR Needham, RE Page Jr, M Delfinado-Baker, CE Bowman, eds), Ellis Horwood, Chichester, UK, 313-324

Swofford DL, Selander RB (1981) BIOSYS-1: a Fortran program for the comprehensive analysis of electrophoretic data in population genetics and systematics. $J$ Hered $72,281-283$

Sylvester HA (1976) Allozyme variation in honey bees (Apis mellifera L). Ph D thesis, University of California, Davis, CA

USDA Agricultural Statistics Board (1993) Honey. National Agricultural Statistics Service, Washington DC

Watkins LH (1967) Harbison's second importation of bees to California. Am Bee J 107, 378-379

Watkins LH (1968) The Mahan-Parsons Italian bee controversy: a new evaluation - Part I. Am Bee J 108 , $436-438,448$ 